\title{
An outline to futureproofing cities with ten immediate steps
}

\author{
Barry D. Wilson BA (Hons) Land Arch, CMLI, RLA, HKILA, HKIUD \\ Founding Director, Barry Wilson Project Initiatives, Hong Kong; \\ Council Member, Hong Kong Institute of Urban Design, Hong Kong; \\ Part-time Professor, University of Hong Kong, Hong Kong \\ (corresponding author: barry@initiatives.com.hk)
}

\begin{abstract}
It's time to accept the fact that the world is changing very, very fast. Technology, business and social structures are rapidly evolving to meet new challenges. However, cities are slow to respond. They take time to plan, finance and construct. By the time they are built they are already out of date. In fact, using past metrics to plan future development, which continues to be the standard practice, is appearing to be a redundant model and proving to be very costly. This paper identifies ten key areas where governments, planners, investors and the individuals responsible for shaping cities, can refocus their priorities and funding in order to more effectively utilise both the limited financial and natural resources available. Entering a period of massive disruption, a paradigm shift is urgently required in the means of conceiving, delivering and managing city development.
\end{abstract}

\section{Introduction}

It seems that a new epoch has now been entered; the Anthropocene, which started last century with the age of digital innovation and has now hurtled into the Fourth Industrial Revolution, involving 'a convergence of technologies and disciplines, nonlinearity, and a re-emergence of digital into material and physical domains', according to Thomas Philbeck, Global Leadership Fellow at the World Economic Forum (Philbeck, 2017: p. 1). It's the speed of current breakthroughs however that has no historical precedent. Evolution is currently at an exponential rather than a linear pace (EB, 2018) and disrupting almost every industry in every country around the world (Figure 1). The breadth and depth of these changes is heralding the transformation of entire systems of production, management and governance, and yet the way cities are being planned, shaped and augmented continues to remain based on longstanding twentieth century principles. Cities, and those that envision them, have been slow to respond to the massive shifts required since the built environment takes time to plan, finance and construct. By the time it is built, development is already out of date. The standard models of development remain linear, using past metrics to plan future expectations. It is increasingly clear that with the massive disruption and exponential changes now manifest, planning by numbers is a redundant model that is applying vast public resources in the wrong places. The sustainable economy is fundamentally changing the ways of life, work and interrelations but requires iterative rather than linear systems of change based on vision, adaptability and integration.

Akin to businesses, city shapers need to be putting far more emphasis on anticipating the potential of a future marketplace rather than extrapolating past results. Adjusting the planning dimension of cities to meet the needs of an unknown but somewhat foreseeable future is necessary, while also starting to make changes in preparedness by providing shock absorbers against surprising eventualities. Planning processes need to rapidly adapt to allow more flexibility and continually realign development thinking to meet this unknown future.

The world's best ever ice hockey player, Wayne Gretzky, is said by Steve Jobs to have come up with the famous quote of 'Skate to where the puck is going, not where it has been' (Jobs, 2007). This has been taken as standard business consultant advice for 15 years in how to achieve success. It 's important today that cities first decide where the puck should arrive and then to make sure it arrives there, otherwise it will be a matter of forever playing catch up. It's also important that a new vision acts as a guide, a vision of living in places much better than presently exist, and that this vision rejects the businessas-usual planning approaches that have brought urban living to this rather desperate point (Figure 2).

\section{Need to change}

The World Sustainable Built Environment Conference 2017 in Hong Kong provided a chance for development experts to gather together at the most influential meeting of its kind, bringing together green building advocates, policy makers, academics and industry practitioners from all over the world to exchange and inform. This was on the back of Donald Trump's decision to pull the United States out of the 'COP21' Paris Climate Agreement and yet, somewhat surprisingly, there was a strong sentiment of bullishness regarding the development sector's ability to meet the urgent and overwhelming level of change needed to redress the balance of a world in socio-economic and political meltdown. The knowledge, 
An outline to futureproofing cities with ten immediate steps

Wilson

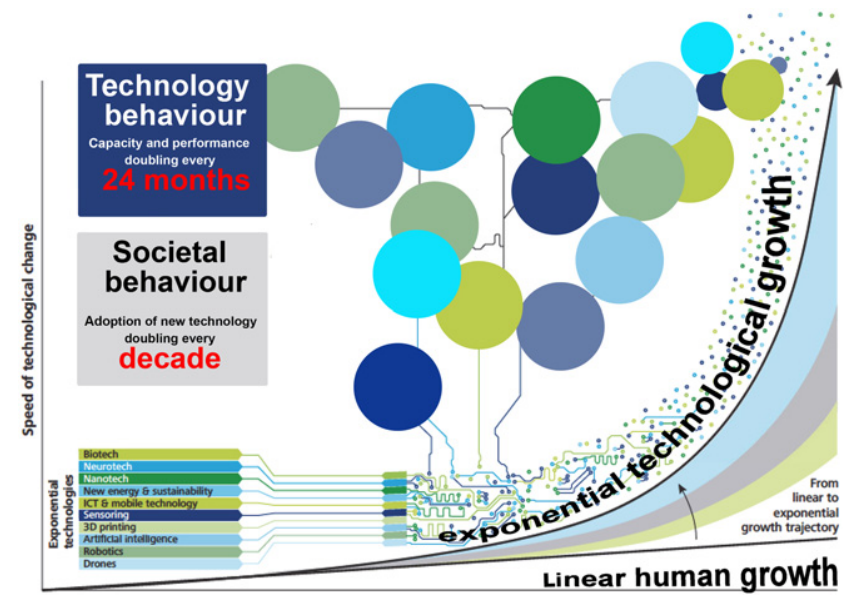

Figure 1. Exponential change of the Fourth Industrial Revolution. Traditional linear planning concepts need to be thrown away (graphic: BWPI - adapted from Deloitte - Industry 4 challenges and solutions for the digital transformation and use of exponential technologies

technology and aspiration appear to exist in droves to change the current pattern of development.

Following the close of the 23rd annual Conference of the Parties ('COP23') in Bonn, it now appears that world's nations are, just about, moving forward to make the significant changes that are required to be in place post 2020 as the commitments of the Paris Agreement come in to affect. Talk is no longer focused on whether it is possible to meet targets, but rather of what might be new, more challenging ambitions, how to achieve rapid and dramatic changes through paradigm shifts in lifestyle, policy and technology. A period of massive transformation, innovation and integration has arrived. As the global thinker Shai Agassi, states, 'Every social transformation requires ... the bravery of Churchill, the vision of JFK, the determination of Reagan, the rare ability to galvanize a country or the world to take the right step for a greater cause. We are standing on the verge of such an event' (Agassi and Zarur, 2008).

\section{Out with the old, in with the new}

Looking at details of how radical new approaches to city life might be implemented, reference can be taken from the 'New Urban Agenda', an outcome document agreed on from the Habitat III cities conference in Quito, 2016. It is intended to guide how the world changes over the next 20 years through the urbanisation efforts of nations, cities and regional leaders, as well as international development funders, UN programmes and civil society (Habitat 3, 2016).

The agenda lays the groundwork for policies and approaches that need to extend and impact far into the future and seeks to create a mutually reinforcing relationship between urbanisation and development, whereby they work in tandem towards what is deemed more sustainable development. Its guidelines offer new approaches in reaching better outcomes for patterns of land use, how a city is formed and how resources are managed. Core issues of adequate housing and sustainable human settlement are the focus but there are seven key factors that will shape the future of cities - the relationship between the environment and urbanisation; risk reduction; urban resilience; ensuring the safety and security of all urban residents, equity in the face of globalisation; democratic development and respect for human rights.

An area of immediate importance has been figuring out how to set-up global monitoring mechanisms to track these issues. UN-Habitat, the agency that focuses on urbanisation, is responsible for overseeing implementation of the New Urban

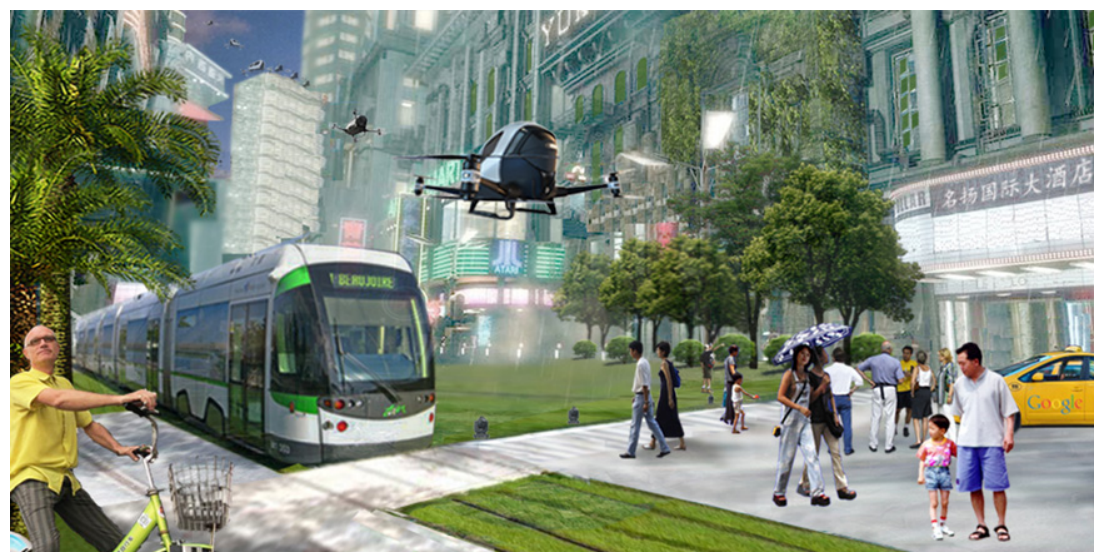

Figure 2. Utopian or dystopian future? How will increasingly populated cities operate a short time from now? (Graphic: BWPI) 
Agenda and its draft 'Action Framework for Implementation of the New Urban Agenda' (AFINUA), which aims to set out the essential ingredients for implementation leadership, measurement and provisions. The 'City Prosperity Initiative' has been established as both a metric and policy dialogue to offer decision makers the conditions to formulate adequate policies based on solid data, information and knowledge and through the Initiative UN-Habitat is offering support to local and national governments in establishing customised monitoring mechanisms, which should allow for better-informed decision making on policies and regulations, city planning and finance management for implementation. So far, 400 cities are signed up.

Many cities are rapidly morphing into mega-regions, urban corridors and city regions whose metropolitan areas are now becoming the major drivers of national economies. Their economic, social and political geographies defy traditional conceptions of the 'city' and those that transform better and faster are going to lead not only those national economies but world economies, benefiting from attracting visionary businesses and hosting a smarter, highly qualified workforce that wants to live and work in the best of quality environments.

What then, should cities be doing immediately to equip themselves sufficiently to meet the demands of climate change, technological revolution and the unknowns resulting from rapid urban transformation? How should they futureproof today's investments so that they are relevant not just for today but in a decade or a century? Here are ten simple, low cost and effective ways to act immediately to shift cities towards the real needs of tomorrow and beyond.

\section{Ten simple futureproofing strategies}

\subsection{Put wellness first}

It's a longstanding fact that healthy, happy populations are more productive and reduce the massive costs of healthcare and social services (Bloom and Canning, 2008; Oswald et al., 2011). Dirty, polluted, inefficient cities have been created, built around economics not people. It's time to prioritise wellness and social prosperity over and above individual and economic factors in reshaping living places. Affordable housing, safer streets, cleaner air and less stress within a fairer society model are necessary. A shift in appreciated values of what is really important in life must highlight the true worth of long-term security, health and wellness above all other matters (Figure 3).

The philanthropists of the nineteenth century saw creating social housing as the greatest means to improving the health and welfare of others while satisfying their own needs through giving (Dreier, 1997; Kottke et al., 2018), while the greatest thinkers and academics put their energies into creating new

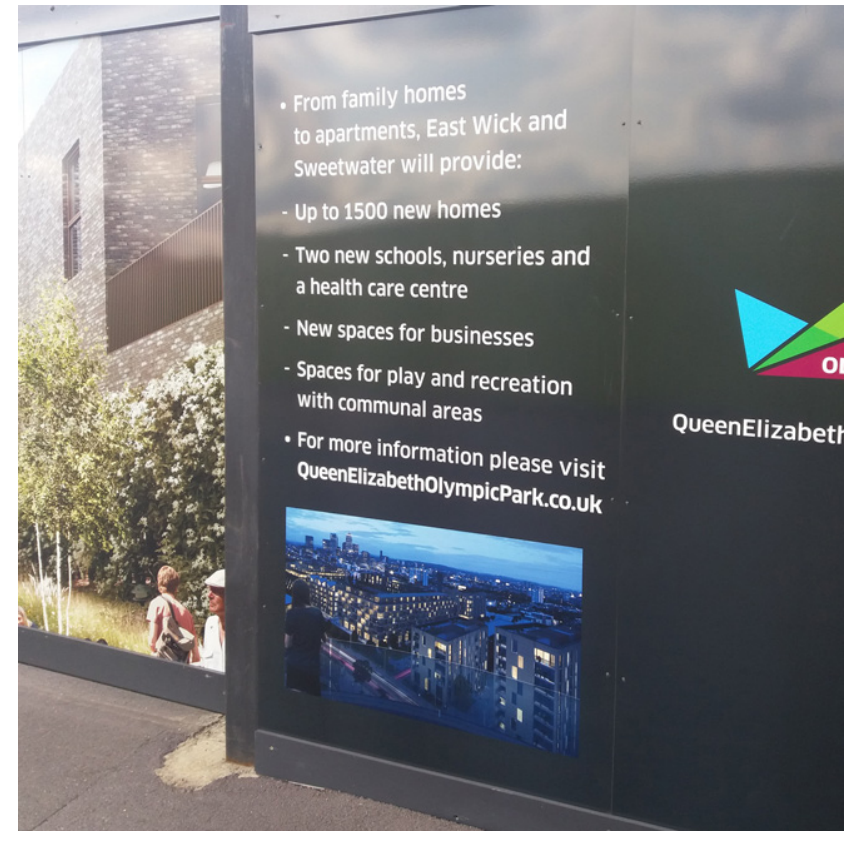

Figure 3. Are new living places providing what people really want or need? How to create safe, vibrant, diverse and supporting communities? (Image: BWPI)

towns, housing types and fairer social systems. George Peabody founded the Peabody Trust to build better and stable housing for London's poor in 1862 (Scott, 2018). The 'Garden City Movement' which was initiated by Sir Ebenezer Howard in 1898 shared the idea that the working class deserved better and more affordable housing (Booth, 2014). In 1979, 42\% of Britons lived in council homes. Today that figure is just under 8\% 'The End of Council Housing' (Harris, 2016). It may just be that the same actions are required today, by starting out on completely new ways to think about equity and housing.

New hybrid homeownership and land rental models, utilising shared or fractional ownership and usage rights are becoming increasingly common (MFG, 2018). Platforms such as 'resident owned communities' provide flexibility for owners to share the management and control of infrastructure, operations, parking and common areas, and are suggestive of a return to traditional concepts of sharing in land assets and the wealth they can create as the benefits of 'the commons' meets a renaissance (Brown, 2012). ROC USA, formed as regional organisations, have helped roughly 8000 families in 129 communities in 12 states join together to buy and run their communities (Brown, 2012). Facilitated by digital technology and the Internet, such models can provide more affordable housing ownership, increased community use of facilities, and opportunities to shape specific services that respond to local aspirations and 
Urban Design and Planning

Volume 171 Issue DP5
An outline to futureproofing cities with

ten immediate steps

Wilson needs through stakeholder involvement and the sense of ownership that delivers. Responsible, shared land management can also improve community cohesion where projects help to build a stronger sense of local identity, pride, confidence, achievement and belonging (French et al., 2008).

\subsection{Develop in the right place}

Flooded streets have become an all too familiar way of life for much of the world's urban population, where more than half of such residents live in flood plains (Michaels, 2016). Recent years have witnessed increasingly severe and frequent flooding which is only going to intensify with ongoing climate change (Abraham, 2018). Rapid urbanisation is massively exacerbating the climate problem however. Continuing population growth and urbanisation are projected to add $2 \cdot 5$ billion people to the world's urban population by 2050 , with nearly $90 \%$ of the increase concentrated in Asia and Africa 'World Urbanization Prospects' (UNDESA, 2014). Flooding is no longer just a problem for farmers living on flood-prone plains; water has become the nemesis of urbanites, where rapidly created new city development has spread uncontrollably at the expense of agriculture, woodlands, streams and ponds. With the loss of existing drainage capacity, urbanisation increases water runoff volume and peak storm discharge (Ali et al., 2011; Dewan and Yamaguchi, 2009; Miller et al., 2002; Sayal et al., 2014). Development has been located without respect to land management, traditional knowledge or sufficient concern for the natural forces of nature.

In the rush to develop more roads, homes, factories and shops, to feed the urbanisation frenzy, governments have turned a blind eye to that most basic concept of 'developing in the right place', and grabbed at the cheap, flat, agricultural flood land previously and deliberately left clear from development. It has been replaced with engineered, high-value, high-risk urban development. Not only is such development irresponsible, it has taken away the very land best suited to feeding burgeoning urban populations. The United States lost 11 million acres of agricultural land with superior soil and weather conditions for growing food from 1992 to 2012 (Nosowitz, 2018). The potential costs of disaster far outweigh the short-term benefits (Figure 4).

The population of Seoul, for example, increased massively through industrialisation and unsurprisingly this created many infrastructure, pollution and environmental problems affecting the everyday lives of citizens. In the 1970s and 1980s, developers moved from the traditional built-up areas on higher ground onto the undeveloped low-lying areas. Not only was this a high-risk policy, the new areas were also developed without adequate consideration for storm water facilities, resulting in repeated flooding.

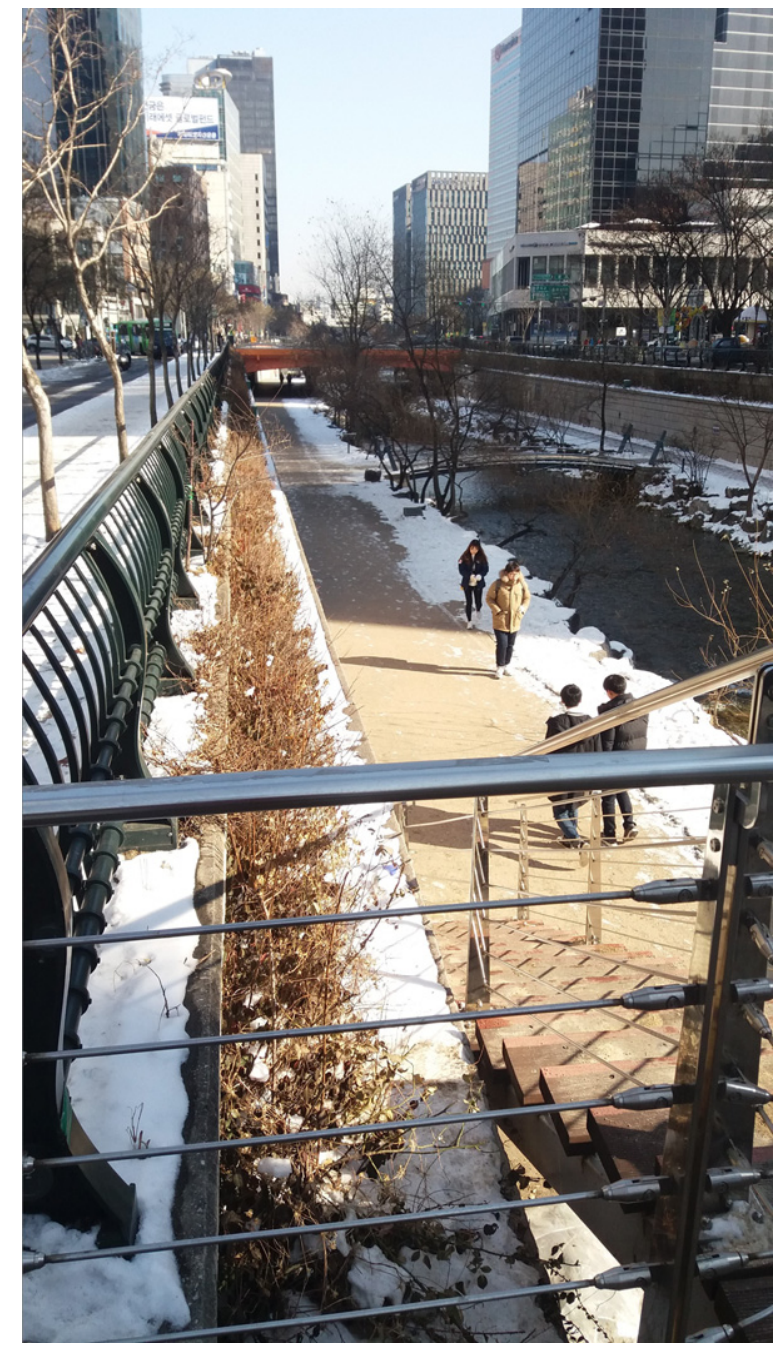

Figure 4. Flood risk threatens to decimate over expanded city development in the coming century. Seoul's Cheonggyecheon urban renewal stormwater project 'daylights' the previously enclosed city stream (image: BWPI)

The loss of natural grounds, green belt and farmland reduced the permeable green zones under which ground water could be recharged. The impervious surface expanded from $7 \cdot 8 \%$ of a city of 2.5 million in 1962 , to that of $47.7 \%$ of a city of 10 million by 2010 . Surface water runoff from heavy rain ended up in the low-lying areas (11\% (1962) $\rightarrow 52 \%$ (2010) 'Seoul's Flood Control Policy' (Young, 2015). There are 40000 basement housing units located in the flood-prone low-lying areas of Seoul. As well as the problem of surface runoff from the massive volume of storm water flowing into these basements, the sewer pipes for basement housing are installed lower than the public sewage system. They back up and regurgitate horribly when it rains. 
Cities are now starting to undertake disaster risk assessment and it's essential in shaping more enlightened thinking about where it makes sense to develop. Adopting 'Low Impact Development' models, which aim to minimise deterioration of environmental quality must become the norm.

\subsection{Connect "green and blue' space}

Green infrastructure, not road infrastructure, should form the framework of both new and augmented planned areas as the best way to shape the pattern of development. Investing in green infrastructure not only contributes to the environment but also creates direct and indirect positive regional effects (Vandermeulen et al., 2011). The components of green infrastructure can be cultural, ecological, developmental, agricultural or recreational and include both managed and unmanaged greenspace (Foster et al., 2011; McMahon, 2000). Together with 'blue' landscape elements linked to pool and pond systems, artificial basins or water courses, they form a 'green-blue system' that can set clear parameters providing 'go/no go' areas for growth. Green infrastructure can act to protect essential ecological processes and systems, preserve working landscapes and resource-based industries, perform environmental services such as managing stormwater, recharging groundwater, reducing the urban heat island effect and cleaning air and water (Benedict and McMahon, 2002) (Figure 5).

Green space needs to be at the heart of city planning, not an afterthought and it all needs to be connected in order to allow flora and fauna to thrive and allow people to move comfortably through it. Cities need green networks without being severed by roads or buildings. Re-planning to link existing green space and waterways with newly created environmental corridors, the bigger the better, should be a starting point in upgrading cities. In identifying green and blue infrastructure resources it is essential to recognise that linkage is key for connecting natural areas and features and for connecting people and programmes. Systems need to be designed that function at different scales, across political boundaries and through diverse landscapes.

The EU Green Infrastructure Strategy, adopted in 2013, highlights actions necessary to be carried out under the European Commission including integrating green infrastructure into key policy areas, improving the knowledge base and encouraging innovation in relation to green infrastructure while assessing opportunities for developing a trans-European Green Infrastructure Network (TEN-G). During the 2014-2020 programming period, it was estimated that green infrastructure would likely receive EU finance amounting to approximately $€ 6397$ million by public EU funds through various funding mechanisms, namely: LIFE+; the European Regional Development Fund (ERDF), the European Social Fund (ESF) and the Cohesion Fund; the European Agricultural Fund for Rural Development (EAFRD) and the European Fisheries Fund (EFF). Initial assessments of the exploratory work suggest that operating at an EU scale rather than at the member state level significantly improves the benefit-cost ratio, contributes to social priorities in addition to the environmental priorities and importantly can also assist to attract private investment 'The Multifunctionality of Green Infrastructure' (EC, 2012).

Funding green infrastructure upfront, as a primary public investment using a full range of available financing options, and grounding its programmes in sound, scientific land-use practice, can it seems, promote a sense of community (Bomans et al., 2010), help reduce crime, fear of crime and anti-social

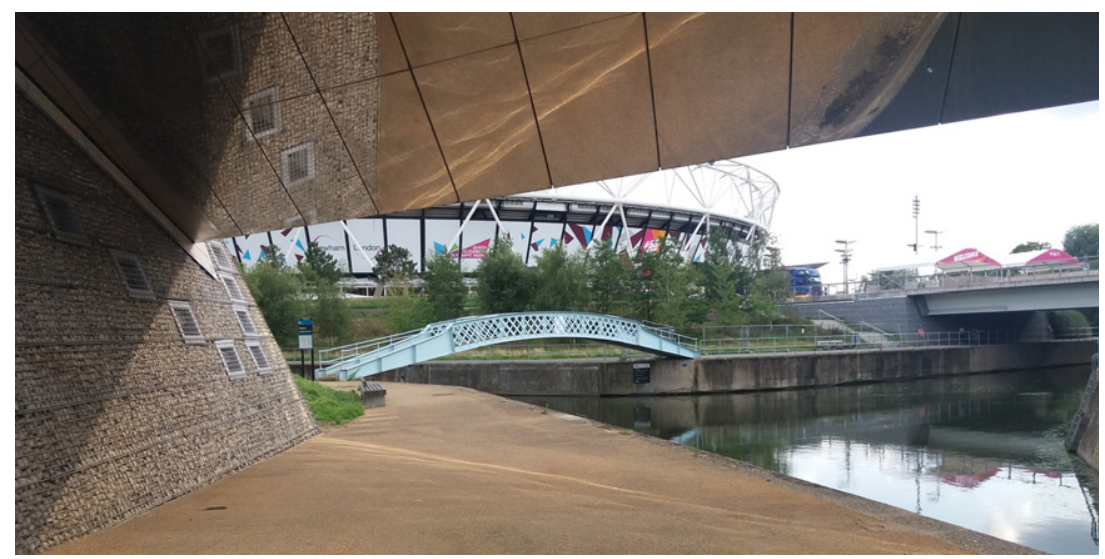

Figure 5. Green and blue infrastructure should form the starting point in shaping development. The London Olympic Park development is part of a huge network incorporating previously neglected rivers, polluted water channels and derelict industrial sites (image: BWPI) 
Urban Design and Planning

Volume 171 Issue DP5
An outline to futureproofing cities with

ten immediate steps

Wilson behaviour (Kuo and Sullivan, 2001) as well as promote opportunities for community involvement and cultural diversity (Coley et al., 1997; Seeland et al., 2009). It can further provide opportunities for exercise, sport, active recreation and improve health as a result of increased physical activity such as walking and cycling (Seymour et al., 2010) and it becomes an essential means to help protect, recreate or rehabilitate landscapes, historic sites or habitats lost or damaged by previous development. Subsequent improvements in environmental quality can facilitate better air and water quality and contribute to improved drainage and flood control.

\subsection{Tear up existing plans}

Many cities and their streets have been shaped first around the horse and cart and then only recently adapted and extended to conform to the needs of motor vehicles. Planners are now quick to first pencil in road alignments as the development guide rather than green or blue infrastructure, but it's immediately time to stop implementing development based on the principles of building costly 'grey' infrastructural frameworks of roads, sewers and drains and then filling in the left-over gaps with zoned development. This is backwards planning since the future holds a limited scope for the continued use of the private motor vehicle in cities. The mayor of Paris, Anne Hidalgo is currently preparing a plan to make the city's public transit entirely free, which will transform the French capital into one of the least car-centric major cities in Europe (Sullivan, 2018). Paris has already announced that petrol cars will be banished by 2030 'Paris Plans to Banish All but Electric Cars by 2030' (Love, 2017), Governments need to take a huge step away and rethink how they really want cities to work, positively planning where things should be and then working out how to best connect them through new and future communications technology (Figure 6).

Autonomous vehicles already function in ways completely different from existing motor vehicles, essentially freeing themselves from the traditional 'rules of the road' and potentially liberating the planning and design of streets since they can pass easily through data managed ground or air space. They are ready and able to solve the 'holy grail' of urban transport planning; the 'last mile problem'. Public transport is all very well, but the private vehicle has been extremely successful in being able to deliver you door to door, in all weather. The problem of getting that last mile from the train or bus stop to your destination has always been problematic, especially when carrying goods, being physically infirm or simply just avoiding the rain. However, who needs their own car when shared vehicles not only have the ability to drop you 'door to door' but automated aerial vehicles (AAVs), currently in testing, can even take you DOOR to FLOOR, utilising roof spaces, refuge floors in tall buildings, terraces and large balconies

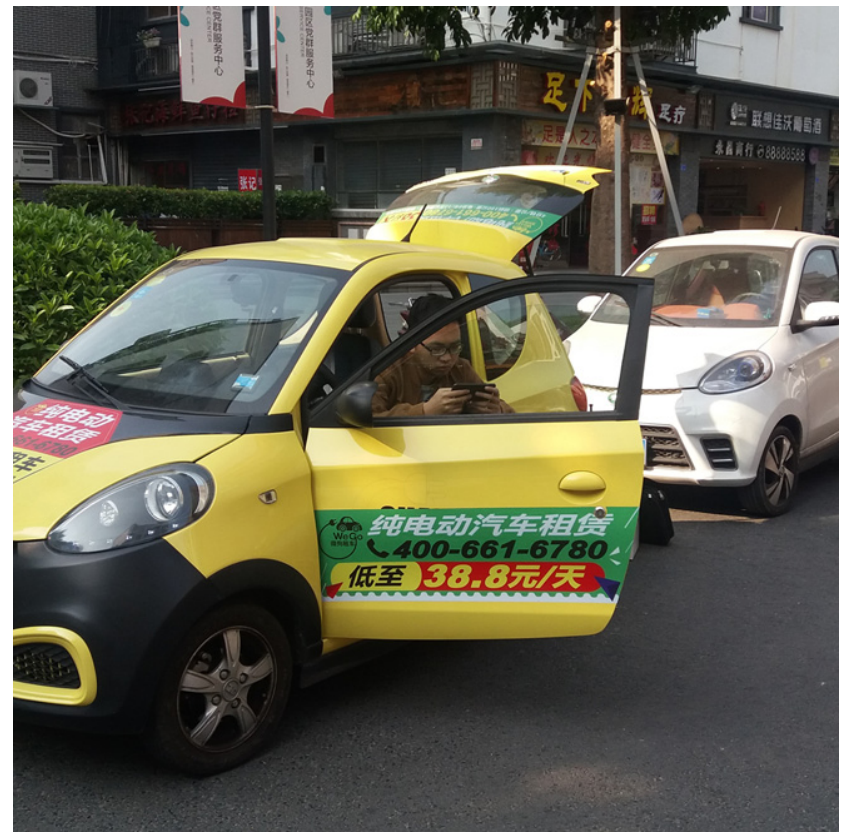

Figure 6. The writing is on the wall for private cars in cities. Shared vehicles used on the streets of Shenzhen, China (image: BWPI)

(Zart, 2017). Buildings and apartments will start to be adapted to even have their own skyports. How are planners building in flexibility for such changes?

The immediate and most obvious benefit from AAV's is their potential to carry out civic duties of emergency response to fire, medical and security needs (Dios et al., 2005; Smith, 2016). Much of the way streets have been developed has been in order to service buildings, particularly in the event of fire. By providing aerial access for fire and maintenance services through high level, externally accessed building hydrants, be it for fighting fires or cleaning windows, it means that vehicle access requirements on the street and around buildings can change. Building codes on emergency vehicle access (EVA) can be relaxed and building arrangements become more varied and flexible.

\subsection{Restrict access to urban roads and adapt them}

This is an easy one. Governments are starting to wake up to the fact that towns and cities and even countries will be increasingly locked into direct global competition for inward investment, tourism, economic activity and employment, with ever more up-to-date information about each and every city available around the world. If a city is packed with noisy, polluting traffic, is subject to legal action for its failure to address toxic air pollution and has continued high incidences of road 
traffic congestion and accidents, then it will start to struggle both in terms of investment and labour supply (EIU, 2011). The sharing economy is also ringing the death knell for private motor vehicles in cities, while it's also inevitable that a variety of automated modules will be the only vehicles in cities in the not-too-distant future as safety, efficiency, insurance costs and congestion all push the market. In fact, car sales in the United States have already been decreasing year on year since peaking in 1986 at almost 11.5 million. Twenty-five years on, annual sales are roughly half that number and the trend can be expected to continue despite the ever-growing population (WA, 2017). A recent study suggests that private car ownership across the United States will decrease $80 \%$ by 2030 (Garfield, 2017). Former vice chairman and head of product development at General Motors, Bob Lutz, is anticipating huge stranded assets in traditional motor vehicles by 2025 , as manufacturers are fully switched to electric production and municipalities automate public transport systems 'Kiss the Good Times Goodbye' (Lutz, 2017). The industry will have most likely already shifted significantly well before then however, meaning that finding fuel stations, repair shops or spare parts for old tech petrol engines will be impossible in urban areas (Figure 7).

There is an urgent need to start paying immediate attention to air pollution caused by tyre, brake and road wear, because it won't be solved by a switch to electric vehicles (SD, 2017). Brake pad dust may come to be reduced through electric vehicle adoption because these mostly utilise regenerative braking, which doesn't use brake pads most of the time, but tyre and road dust will remain a problem. Several countries and regions have implemented or are in the process of implementing programmes to improve tyre efficiency and safety, such as United States, Japan, European Union and South
Korea (Pike, 2011). Rating and labelling programmes along with drawing up compliance standards are important first steps, enabling both consumers to select, and ensuring manufacturers offer, more efficient tyres. The installation of tyre pressure monitoring systems (TPmSs) as a safety and efficiency measure should become an effective strategy in reducing wear, aided by the global spread of the technology.

While Europe and America have introduced a whole gamut of initiatives ranging from congestion charging; speed cameras; car-free zones; low-speed streets; removal of on-street parking; Woonerf; Shared Space; and Homezones, the biggest improvements can be made however through removing roads altogether and adapting urban areas for comfortable, safe walking and biking. Pedestrianisation of city centres began to gain popularity in Europe about 50 years ago and is now a feature of most developed city-centre plans (Melia and Shergold, 2016). The sort of measures used include the shading of pathways, attractive paving materials, use of materials to dissipate heat, integration with public transport stations, landscaping and better pedestrian corridor links with major destinations. Provision of adequate pedestrian facilities improves air quality by keeping traffic away from sensitive, high exposure locations and by encouraging walking as the preferred mode for short trips. A study of Nuremberg, Germany shows that significant improvements in air quality have been achieved since pedestrianisation was introduced into the city centre in the early 1970s (Wallström, 2007).

At this time, to be building new roads and the supporting infrastructure for old technology in and around cities is just burning money and extending the inefficient use of land. Stopping road 'improvements', limiting access, adapting them to new uses and starting to remove them completely will

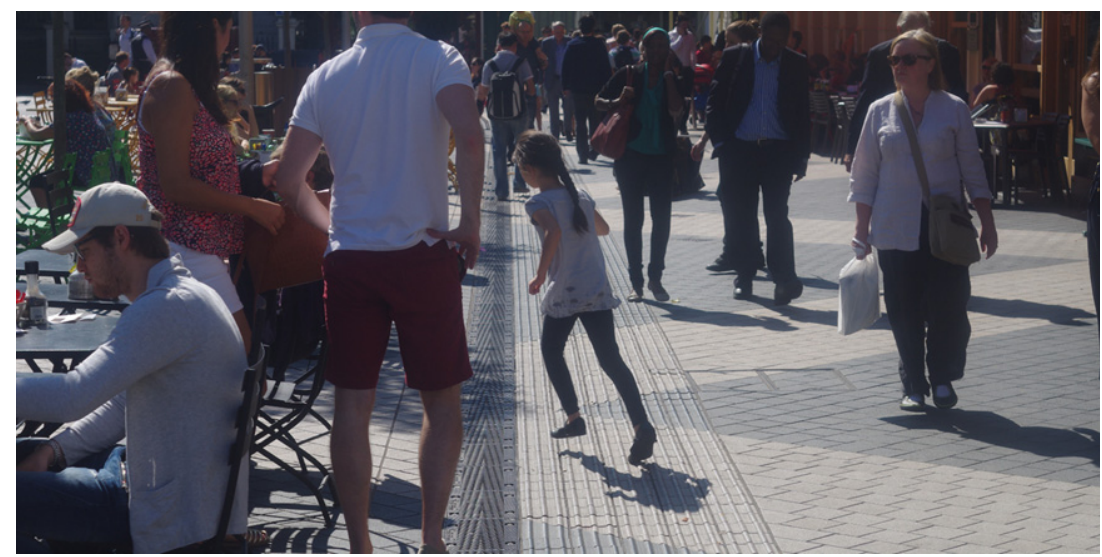

Figure 7. Streets are for people. Exhibition Road, London shows how vibrant city spaces can be safely and attractively incorporated (image: BWPI) 
Urban Design and Planning

Volume 171 Issue DP5
An outline to futureproofing cities with

ten immediate steps

Wilson promote more liveable cities and hasten a rethink of how cities should operate.

\subsection{Remove parking}

While roads facilitate car journeys its actually parking that generates them. The land area dedicated to vehicles in many American cities is over 50\% and while European cities are typically closer to $25 \%$, it's still a vast area of public realm provided at the expense of other, more productive investments 'Automobile Use and Land Consumption: Empirical Evidence From 12 Cities' (McCahill and Garrick, 2012). Traffic congestion rightly earns tremendous attention, but parked cars shape daily urban life even more so. Off-street parking is typically of dull paved space or in banal structures while on-street parking narrows streets, causes congestion through waiting and searching, creates a hostile street environment and blights both the air quality and appearance of streets. Land-use patterns have changed to reflect car use with shops and services needing to provide vehicle parking areas. Society has become hard-wired to increasing levels of car dependency (Figure 8).

Where building density is low, parking is extremely land intensive and where density is high, parking is capital intensive, making its cost substantial in either case. What's more, parking tacitly subsidises those most able to afford automobile ownership since cars are parked most of the time and ownership is

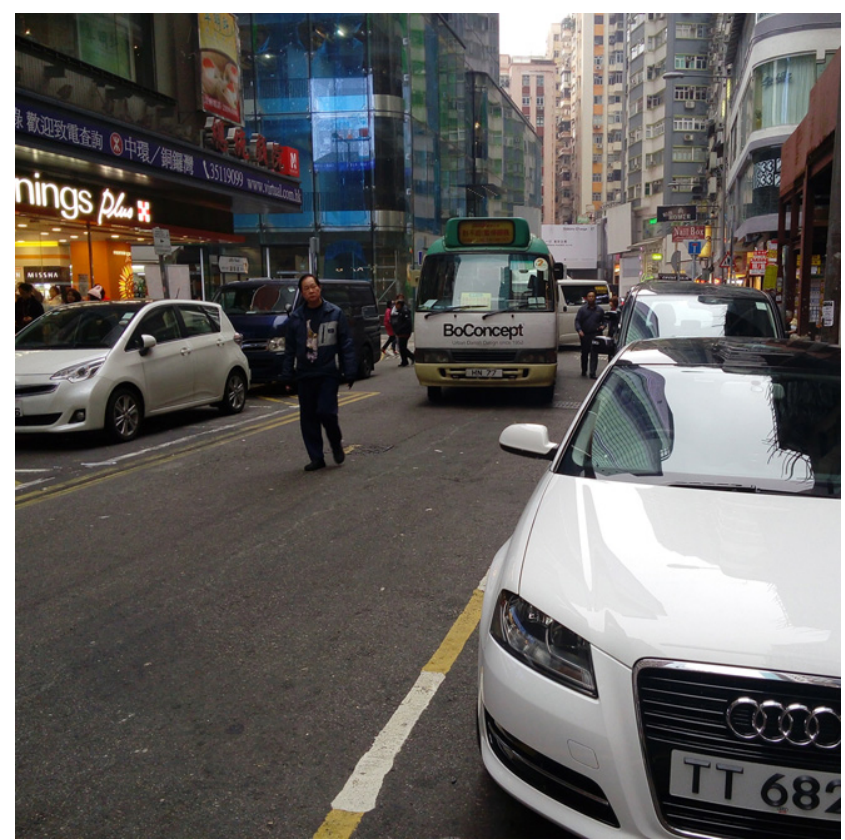

Figure 8. Urban space has so much more to offer than just parking. Subsidising the wealthy by providing on-street parking in overcrowded Causeway Bay, Hong Kong (image: BWPI) easier if a car can be cheaply and reliably stored when it is not being driven. In those countries where minimum parking requirements are set with land development in order to ensure adequate parking supply, such as the United States and China, the cost of parking is aggregated into the cost of development, thereby increasing the prices of all goods and services sold at sites offering parking. Transport planner Donald Shoup suggests that the external cost of parking in cities may be greater than all the other external costs combined, where minimum parking requirements increase the cost of constructing a shopping centre by up to $67 \%$ if the parking is in an aboveground structure and by up to $93 \%$ if the parking is underground 'The High Cost of Minimum Parking Requirements' (Shoup, 2014).

The widespread availability and affordability of car travel has brought freedom to society in many ways but these benefits have been obtained at a substantial price, and one that generally falls most heavily on the poorest and most vulnerable in society; those who are generally unable to benefit from private vehicle use themselves suffer from the effects of other people's travel. The negative impacts include deaths, injuries, stress, air and noise pollution (Douglas et al. 2011). In the United Kingdom, the cost of community severance and the loss of social cohesion (the 'barrier effect' due to transport infrastructure) is classified as an 'impact that is currently not feasible to monetise'; however, research from the Institute of Transport Economics in Oslo suggests that it is even greater than the estimated cost of noise pollution and almost equal to the cost of air pollution 'Fairness in a Car Dependant Society (SDC, 2011)'. The UK Department for Transport, estimated the costs to urban areas in 2009, based on excess delays, accidents, poor air quality, physical inactivity, greenhouse gas emissions and noise pollution as being up to $£ 56$ billion; significantly more than was brought in by road taxes 'Creating Growth, Cutting Carbon - Making Sustainable Local Transport Happen' (DoT, 2011).

With the conversion to mass transport and shared vehicles in urban areas, parking requirements should relax significantly as such vehicles can be employed 24/7, whereas private vehicles are parked for the majority of their lives; an incredibly inefficient use of space and resources. Removing on-street parking to free up urban space and removing minimum parking quotas, allows the potential for more interesting spaces, more greenery and more efficient land use. Just think what can be done without all that wasted space.

\subsection{Encourage ageing in place}

With an ageing population demographic, it 's worrying how the younger generations are going to be able to manage to support older family members. It is a well-researched fact that 
people worldwide would prefer to stay in their homes as they get older. In the United States, for instance, $90 \%$ of adults over the age of 65 report that they would prefer to stay in their current residence as they age 'Creating Environments for Successful Aging' (Kochera et al., 2005). The elderly find change challenging. In China in particular, with the current move to urbanisation and massive demographic shift caused by an ageing population and the one child policy, the challenge in providing adequate elderly care is very real. As a result of the 'one child policy' siblings are uncommon, meaning that one child must often care for two parents and four grandparents, leading to 'The 4-to-2-to-1 ratio' (Bailey et al., 2012). This massive burden on the working generation has put pressure on the Confucian traditions that dictated children were responsible for taking care of their elders (Figure 9).

China's latest 5-year plan hints at the scale of the problem stating that 'As an integral part of elderly care, families and communities are asked to take their share of responsibilities. Community elderly care centres will receive more government funding' (SCN, 2017).

Beijing local government has outlined the '9064' framework for a care-model to be implemented by 2020 , whereby $90 \%$ of elderly are expected to spend their last stages of life at home and be cared for by their family (home-based), $6 \%$ are expected to enjoy their last stage of life at home with community support (community-based), and just $4 \%$ are expected to be supported by long-term care institutions (institution-based) (Wang, 2017).

Ageing in place is going to require a troublesome shift in the way societies think about the role of communities and the way services are delivered to individuals. Ageing can make it increasingly difficult to perform certain tasks; there is a multilayered complexity of needs that is initially fairly straightforward but becomes increasingly challenging with ageing, illness or disability. Strong family and local support can permit individuals to remain within their homes and communities; however, it is the unchartered potentials of the tech sector to be able to deliver remote monitoring and doctoring that offers a radical change in support systems.

It 's becoming increasingly necessary to develop new and broad ranges of community-based assistance to meet ageing needs, including affordable and accessible housing, convenient transportation, work, education and volunteer opportunities, access to health and support services, participation in civic and cultural activities and intergenerational connections. Volunteers and NGOs are increasingly expected to fill the gaps left by insufficient public-sector funding, especially in developing countries and might be expected to play an increasingly important role in supporting elderly residents. In the

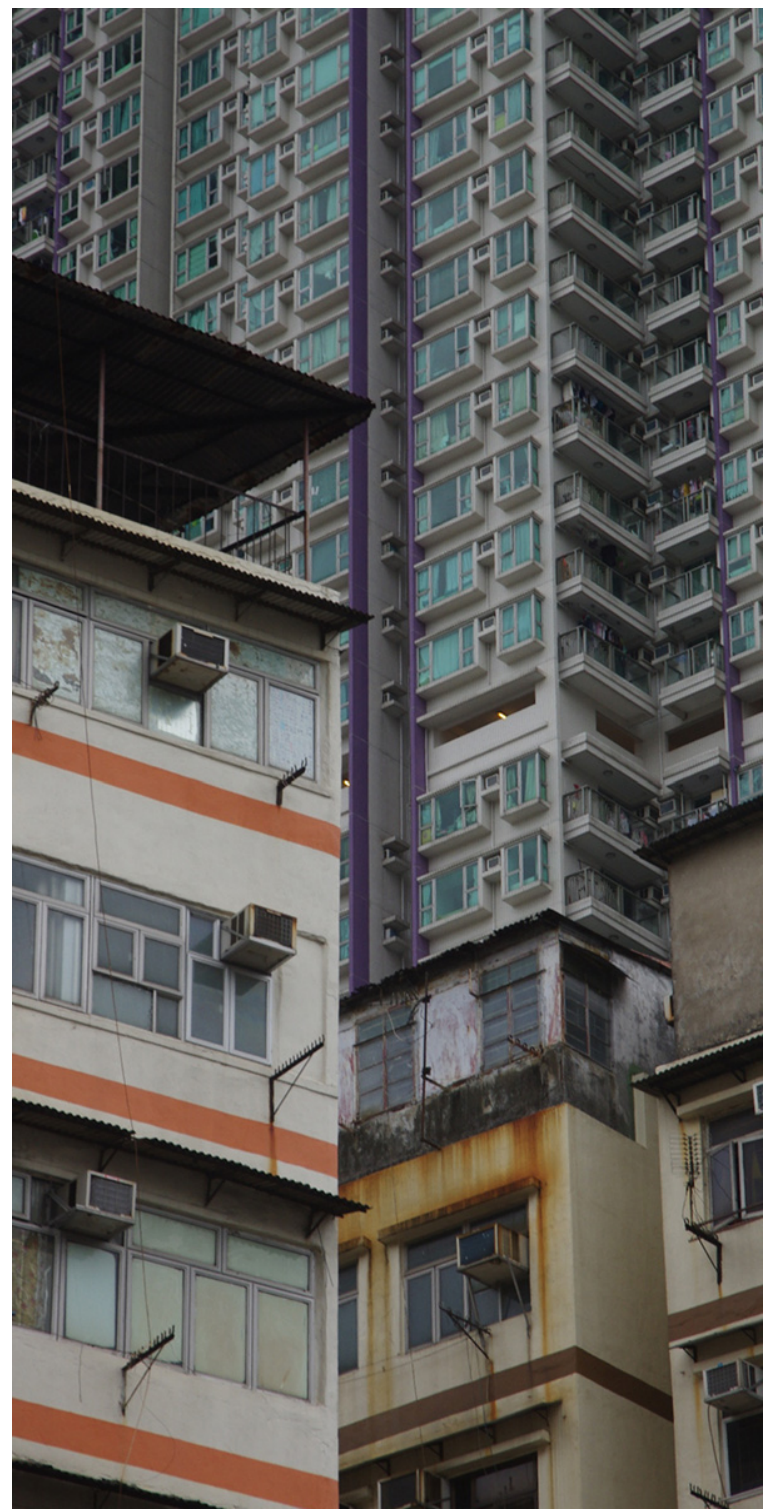

Figure 9. More variety in housing mix is essential. Flexibility to stay in a community requires a variety of housing product (image: BWPI)

Philippines, HelpAge International is already on the ground with its local partner, the Coalition of Services of the Elderly (COSE), to encourage and assist the elderly to address important issues within the community. As well as health and nutritional support programmes for older residents, COSE also coordinates with the government to offer home care and psychological support and train volunteers for 'active ageing' initiatives.

Age segregation is particularly problematic in that it creates divides in society that contribute to ageism and deprive 
Urban Design and Planning

Volume 171 Issue DP5
An outline to futureproofing cities with

ten immediate steps

Wilson everyone of opportunities for intergenerational learning (Blumenthal, 2014). This tends to be less of a problem in Asian societies than those in the west; however, well planned and diverse communities can encourage intergenerational interactions to everyone's benefit. Children in particular can sustain seniors' ability to age in place, while older adults can enrich the lives of the young and share their knowledge and skills (Parker, 2016).

Governments, both local and national, must work out how to further urban regeneration without displacing communities, while financers, real estate companies and designers must urgently start to solve the requirements ageing demographics and their desires to stay within their communities and close to their families and caregivers.

Housing development must become more diverse and innovative in the product mix put into market and increase the flexibility and adaptability of accommodation to appeal to a wider market. The traditional approach of specifically targeting distinctive demographic groups with real estate product suited to those markets, has the problem that in doing so it is difficult to creating interesting, diverse and functional communities while ageing in place becomes particularly problematic, since residents will need to move away to meet their changing life needs over time.

The United States currently leads the way in the field of creating elderly communities, and trends there demonstrate an increasing sophistication of the market and a response to the expectations of the post-war, baby-boomer generation. Large, gated, age-restricted active senior housing communities that often didn't allow children are becoming a thing of the past (Nyren, 2014). Communities are now expected to become inter-generational and encourage connectivity between residents and the community at-large. Active residents look to be able to enjoy the benefits of what the wider area has to offer particularly within transit-oriented districts and walkable environments where shops, restaurants, libraries and theatres form a key component of their lifestyle choices. Provision or access to ballcourts, pools, spas, activity spaces and outdoor fitness and meditation areas is expected. More attention is being paid to health and wellness values whist multiple dining venues are seen as a must, including a diversity of price-point options suitable to diverse communities (Nyren, 2014).

\subsection{Embrace density}

Currently, 54\% of world's population lives in urban areas, a proportion that is expected to increase to $66 \%$ by 2050 'World Urbanization Prospects' (UNDESA, 2014). With more and more people moving to cities there is a danger of them sprawling out of control. Low-density suburban sprawl creates its own problems in that it is very land inefficient, leads to increased infrastructure costs, does not promote efficient transport solutions and can be socially derelict (Mtantato, 2013). As world populations increase, cities must become more compact, with high-density neighbourhoods being created to support social and community vibrancy, high quality yet cheap public transport services and a movement to the use of shared facilities and their upkeep. Tomorrow's cities are going to have to be taller, but they can also be greener and also be great living places (Figure 10).

Processes of sharing, matching and learning allow industries to flourish in higher density populations that would not be as efficient at a smaller scale (Deichmann, 2017). As countries urbanise, incomes go up and dense cities can actually be more healthy as well. New data demonstrate that housing densities of less than 1800 units per square kilometre, including those in suburbia, increase the chances of someone being obese by about 10\% (Chinmoy et al., 2017). Lower-density development encourages sedentary behaviour, including driving to stores and work, and less cycling and walking. By contrast, living in areas above the 1800 units per kilometre density threshold can have a $10 \%$ lower chance of becoming obese, even in inner cities where people are more likely to live in apartment blocks and smaller homes 'Association Between Adiposity Outcomes and Residential Density (Chinmoy et al., 2017).
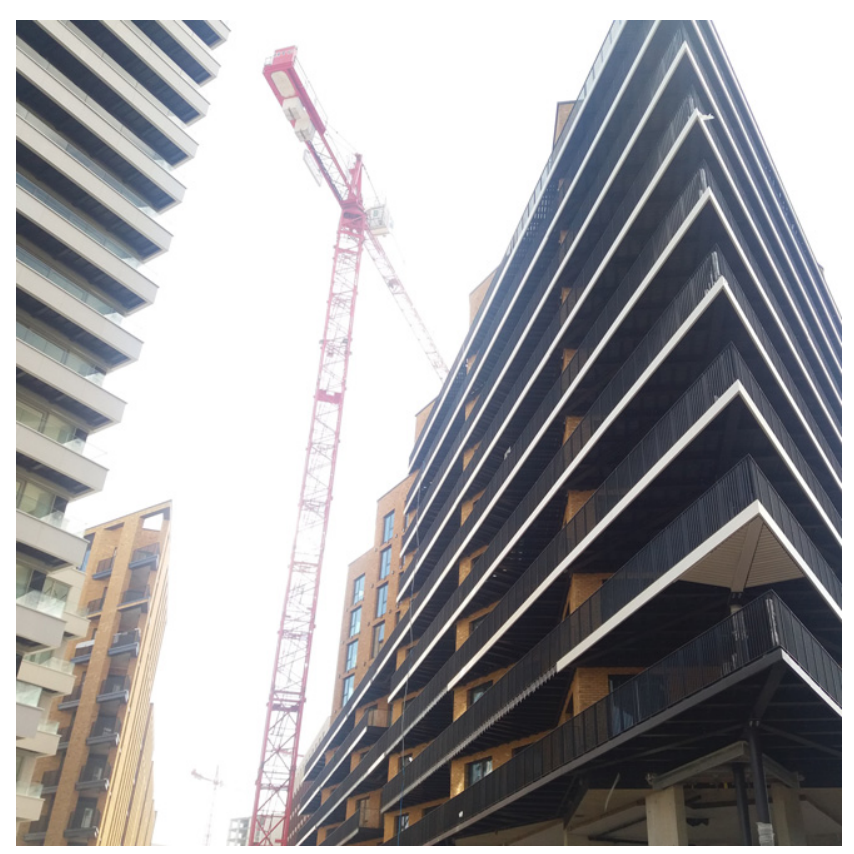

Figure 10. Compact or sprawling? Dense apartment living optimises valuable resources. Density in housing provision can provide happier, healthier living (image: BWPI) 
Trends are rapidly and necessarily moving towards smaller living spaces, and the sharing economy has already started to create new ways of thinking about many basics of life, including ownership, transport and accommodation. The Airbnb phenomenon shows new ways of thinking about utilising housing resources (Wachsmuth et al., 2017) and a renaissance in prefabricated housing and is coupled with a societal willingness to live more 'spartan' lifestyles (Hong, 2016). 'Prefab' utilising both modular and panel systems, is starting to provide wider housing opportunities due to recent technological advances in construction quality. Micro houses, including mobile homes that can be fully constructed off-site and moved into place on wheels can act as a source of both temporary or long-term affordable housing, utilising private urban land such as garden space. No land ownership is required and building codes don't necessarily apply (Modulartoday, 2018), while their standardised manufacture means costs are minimised (HD, 2018).

\subsection{Celebrate water}

The realisation that water is a valuable resource must sink in fast. Modern cities, concrete caked and bitumen baked, have fallen foul of the belief that natural environmental balance is unimportant and can be overcome with new technology and engineered systems built to manage storm water, including underground drainage pipes, storage tanks and deep tunnel systems (Carter, 2013; Madden, 2010). Such systems have been useful; however, they are expensive, inflexible, limited and cannot replace the efficiency and balance of naturally evolved waterways and flood systems, including the resilience and adaptability they provide. City planners and managers have paid too much attention to the construction of drainage facilities, which has increased the financial burden yet reduced water resources (Zhang et al., 2012).

Cities must invest heavily to transform not only their flood control measures, but their whole approach to stormwater management. Policies need to go beyond simple flood prevention to that of holistically embracing all of the environmental, urban planning and transportation aspects, realising that the key elements that affect flood damage are not just rainfall, but a combination of geography, land use and the sewage system (Figure 11).

It is essential to restore natural water circulation and increase the amount of rainwater absorbed into the ground. Rainwater should be slowed, collected and stored as groundwater, rather than putting pressure on engineered solutions that are rapidly insufficient (Drake, 2015). Green infrastructure plays a crucial role and where city rivers have been sent underground into concrete channels and storm drains, these can be 'daylighted' and re-integrated into urban greening and amenity corridors.

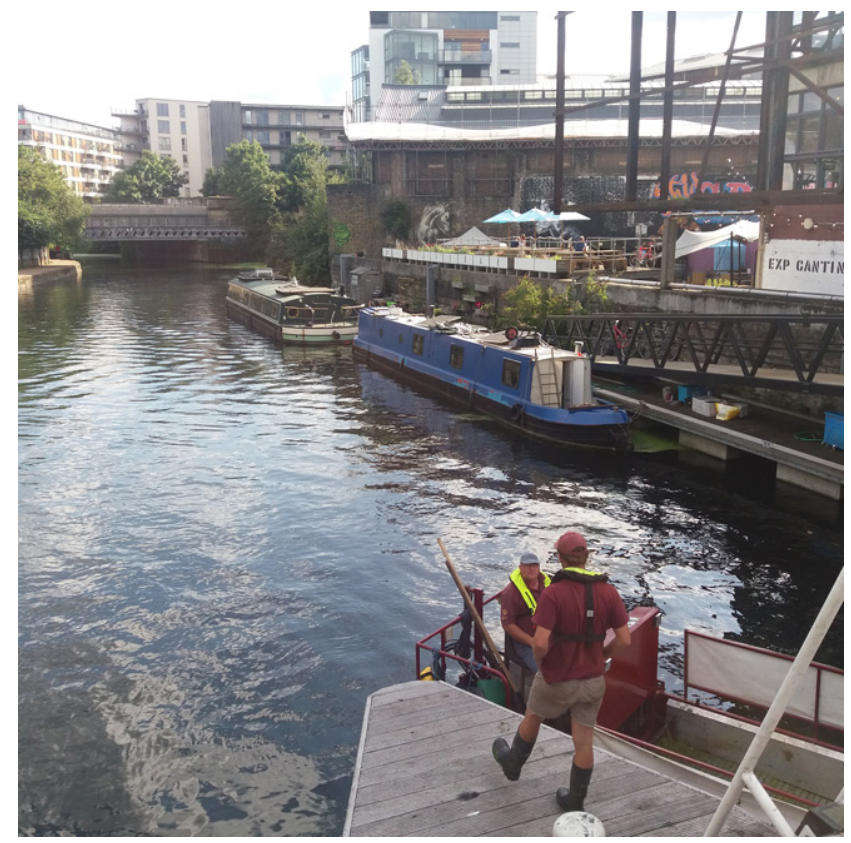

Figure 11. People just love getting next to water. Cleaning and refurbishment of the Old Ford Locks on the River Lea, London has reinvigorated the surrounding area (image: BWPI)

Removing highways and improving the permeability of roads and pavements can also help. Cities can also become more prepared and responsive by involving the whole populace through new models of integrated water management at the micro scale, with the widespread introduction of domestic rainwater storage facilities, along with educating and empowering citizens to make best use of them (Gold, 2013).

It is critical to ease the burden on existing sewage systems and rainwater pumping stations and help cities to be more prepared for urban flooding. New cities must become super sponges, developed to avoid flash floods while being able to adapt street spaces with pools and rivers for cooling, irrigation, cleaning and just sheer delight!

\subsection{Monitor standards}

Green building technologies are commonplace, inexpensive and should be seen as minimum standards rather than a premium product. The term 'green' is most likely just a temporary idea and soon requirements for 'green' will become business as usual (Tong, 2017). A 'green building' should just be a 'building', in the same way as a 'colour TV' is now just a 'TV'. Green will become the new standard. Costs of production are falling rapidly as green product use is scaled up (GBCSA, 2018). Creating and continually raising thresholds 
Urban Design and Planning

Volume 171 Issue DP5
An outline to futureproofing cities with

ten immediate steps

Wilson for ALL buildings, neighbourhood developments and interior decoration to meet ever greener standards should be a basic requirement. However, it's the monitoring of the performance both buildings and urban public space in terms of heat gain, energy and water use, air quality, health and participation that is essentially needed to be introduced in order to continue to learn how to continue to create better urban places to live (Figure 12).

Up until now certification products and green awards have been essential in promoting both the business case and health benefits of sustainable development in the face of perceived higher costs. Such tools are potentially likely to become unnecessary as real-time evaluation continues to take hold in the market and the consumer will be taking control of monitoring the actual quality performance of both their indoor and outdoor environments. The term 'smart city' has been used with various definitions of how a city can develop smartly, however, they all include the monitoring of big data and the concept of utilising the Internet of things (IoT).

Outside pollution levels in cities can already be measured through phone apps, and real-time traffic congestion can be identified. Increasingly, monitoring the performance and health aspects of every part of the buildings and spaces that are occupied will become the norm in order to measure intensity of use, wear and tear, optimum light, temperature or air quality levels. It is unfathomable that so much time is spent indoors yet so little is done to improve the health and wellness aspects of such places, but this will change fast. Specific conditions integrated into the architecture and landscape design of spaces can achieve improved human happiness, learning and productivity leading to heightened employee attraction and retention (Allen et al., 2015; Jones and Laquidara-Carr, 2016). Healthy places don't cost more to build (Landreneau, 2017), they just need more availability of information and monitoring
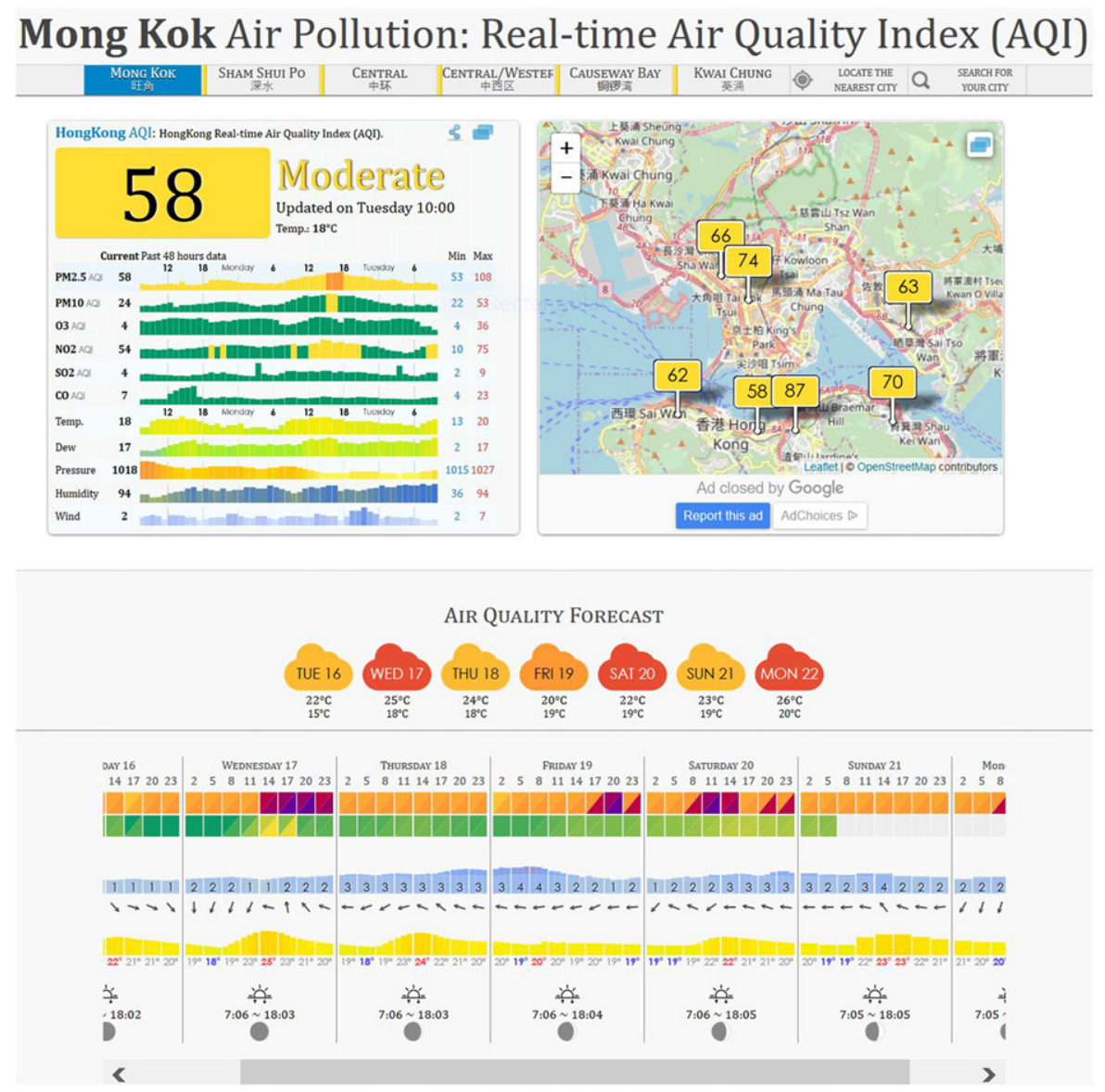

Figure 12. Smart city technologies and the loT will be the key to efficient resource management. World air quality can now be publicly monitored in real time (source: AQICN.org. Image: BWPI). A full-colour version of this figure can be found on the ICE Virtual Library (www.icevirtuallibrary.com) 
that will soon be readily available, much the same as in rating a restaurant for its food or an hotel for its amenities. Such technology is already in the marketplace and urban dwellers will react accordingly, with places and cities having to become more competitive through health benefits, reduced energy use and promotion of sustainable behaviour. The business sector is already working with universities and civic planning authorities to develop data-driven systems for transport, waste management, law enforcement and energy use to make them more efficient and improve the lives of citizens, along with the potential to make big profits of course. The key element is that objects will utilise sensors and communicate with each other for efficiency; the tech element of the 'Smart City'.

\section{Conclusions}

The last century was 'command and control', but this century is 'suggest and select'. Tomorrow's population is instantly informed about all and any matter, can independently evaluate through social media and ultimately mandate an action or product with transparent and real-time reaction. Market forecasts have assumed business as usual or traditional usage patterns, without anticipating shifts to be as fast or disruptive as they continue to be, where the acceleration of change is increasing exponentially. This implies that the planning of cities, something generally carried out over several years based on accumulated past data and scientific study, is hugely out of sync with current and future aspirations of society and that governments in particular are failing to react, regulate and adapt at the speed necessary to accommodate change. Shared and autonomous vehicles will soon be part of an ecosystem of intelligent communication systems and built-fabric agents that act as personal-data vendors. The information they use to select a route will be based on all the data they have about a customer's lifestyle preferences, contacts and needs. Every part of cities will be alive, responsive and evaluated. The arrival of automated transport and servicing should mean safer streets along with less roadside pollution for both cyclists and pedestrians. It should mean creating more interesting spaces that are less standardised, include more greenery and have fewer obstructions. It should mean that city streets in the near future will not need traffic lights, road signs, kerbs, railings or protective barriers. These changes are happening at an exponential rate but cities are not prepared for them, nor do they have the regulatory mechanisms to adjust quickly enough to meet these changes.

With little existing data and local experience to follow, the Chinese economic revolution has been built on the back of 'copy and adapt' tactics, resulting initially in huge wastefulness and inefficiency but also now leading to a new spirit of realtime trial and error in development, and to rapid change in thinking and execution. Bold leadership and envisioning, coupled with a strong tendency towards regulation and adaption after implementation, through 'iterative' processes rather than the extensively planned, tested and pre-regulated 'linear' processes established by the developed world, is starting to appear more effective in rapidly addressing the current shifts of the new industrial revolution, including threats of population migration and climate change.

This raises the question of whether governments in themselves can remain effective based on their own traditional models or whether in fact new world systems are urgently necessary; governments whose type, form and role can be continually re-assessed and their resulting processes adjusted rapidly in order to be able to adequately serve their people through the twenty-first century.

\section{REFERENCES}

Abraham J (2018) Climate change is increasing flood risks in Europe| John Abraham. The Guardian, 8 February. See https://www. theguardian.com/environment/climate-consensus-97-percent/2018/feb/08/climate-change-is-increasing-flood-risks-in-europe (accessed 14/06/2018).

Agassi S and Zarur A (2008) Transforming Global Transportation, Fuel Independence at Country Level as a Business Opportunity. Better Place White Paper, Israel.

Ali M, Khan J, Aslam I and Khan Z (2011) Simulation of the impacts of land use change on surface runoff of Lai Nullah basin in Islamabad, Pakistan. Landscape and Urban Planning 102(4): 271-279.

Allen J, MacNaughton P, Satish U et al. (2015) Associations of cognitive function scores with carbon dioxide, ventilation, and volatile organic compound exposures in office workers: a controlled exposure study of green and conventional office environments. Environmental Health Perspectives 124(6): $1-32$.

Bailey D, Ruddy M and Shchukina M (2012) Ageing China: changes and challenges. BBC News, 20 September. See http://www.bbc. com/news/world-asia-19630110/ (accessed 16/05/2018).

Benedict MA and McMahon ET (2002) Green infrastructure: smart conservation for the 21st century. Renewable Resources Journal 20(3): 7.

Bloom DE and Canning D (2008) Population Health and Economic Growth. World Bank Publications, Washington, DC, USA.

Blumenthal S (2014) Aging in Place: An Intergenerational Priority. HuffPost, New York, NY, USA. See https://www.huffingtonpost. com/susan-blumenthal/post_8756_b_6315082.html (accessed 14/06/2018)

Bomans K, Steenberghen T, Dewaelheyns V, Leinfelder H and Gulinck H (2010) Underrated transformations in the open space - the case of an urbanized and multifunctional area. Landscape and Urban Planning 94(3-4): 196-205.

Booth R (2014) New Garden Cities Must Offer Genuinely Affordable Homes, Says Charity. The Guardian, 22 April. See https://www. theguardian.com/politics/2014/apr/22/garden-cities-affordablehomes-tcpa-ebbsfleet-howard-letchworth (accessed 13/06/2018).

Brown R (2012) How Trailer Park Cooperatives Could Benefit Maine. Bangor Daily News, 11 October. See http://bangordailynews. com/2012/10/11/opinion/how-trailer-park-cooperatives-couldbenefit-maine/ (accessed 14/06/2018). 
Urban Design and Planning

Volume 171 Issue DP5
An outline to futureproofing cities with

ten immediate steps

Wilson
Carter T (2013) Smart cities: the future of urban infrastructure. $B B C$, 22 November. See http://www.bbc.com/future/story/20131122smarter-cities-smarter-future (accessed 06/06/2018).

Chinmoy S, Webster C and Gallacher J (2017) Association between adiposity outcomes and residential density: a full-data, crosssectional analysis of 419562 UK Biobank adult participants. The Lancet 1(7): e277-e288.

Coley RL, Sullivan WC and Kuo FE (1997) Where does community grow? Environment and Behavior 29(4): 468-494.

Deichmann U (2017) High-Density Cities Hold the Key to Transforming Economic Geography. World Bank, Washington, DC, USA. See http://www.worldbank.org/en/news/feature/2017/01/26/high-densitycities-hold-the-key-to-transforming-economic-geography (accessed 14/06/2018).

Dewan AM and Yamaguchi Y (2009) Land use and land cover change in Greater Dhaka, Bangladesh: using remote sensing to promote sustainable urbanization. Applied Geography 29(3): 390-401.

Dios J, Merino L and Ollero A (2005) Fire detection using autonomous aerial vehicles with infrared and visual cameras. IFAC Proceedings Volumes 38(1): 660-665.

DoT (Department of Transport) (2011) Creating Growth, Cutting Carbon - Making Sustainable Local Transport Happen. The Stationary Office, Norwich, UK. ISBN: 9780101799621.

Douglas M, Watkins D, Gorman D and Higgins M (2011) Are cars the new tobacco? Journal of Public Health 33(2): 160-169.

Drake J (2015) Stormwater Innovations Mean Cities Don't Just Flush Rainwater Down the Drain. The Conversation, Boston, MA, USA. See https://theconversation.com/stormwater-innovations-meancities-dont-just-flush-rainwater-down-the-drain-40129 (accessed 14/06/2018).

Dreier P (1997) Philanthropy and the housing crisis: the dilemmas of private charity and public policy. Housing Policy Debate 8(1): 235-293.

EB (Encyclopedia Britannica) (2018) Moore's Law|Computer Science. EB, Chicago, IL, USA. See https://www.britannica.com/ technology/Moores-law (accessed 25/06/2018).

EC (European Commission) (2012) The Multifunctionality of Green Infrastructure. Science for Environment Policy In-depth Reports| European Commission's Directorate-General Environment, Brussels, Belgium. See http://ec.europa.eu/environment/nature/ ecosystems/docs/Green_Infrastructure.pdf (accessed 13/06/2018).

EIU (Economist Intelligence Unit) (2011) Liveanomics Urban Liveability and Economic Growth. The Economist Intelligence Unit, London, UK.

Foster J, Lowe A and Winkelman S (2011) The Value of Green Infrastructure for Urban Climate Adaptation. Center for Clean Air Policy, Washington, DC, USA.

French C, Giraud K and Ward S (2008) Building wealth through ownership: resident-owned manufactured housing communities in New Hampshire. Journal of Extension 46(2): 127-128.

Garfield L (2017) Only 20\% of Americans Will Own a Car in 15 Years, New Study Finds. Business Insider, Singapore. See https://www. businessinsider.sg/no-one-will-own-a-car-in-the-future-2017-5/?r $=\mathrm{US} \& \mathrm{IR}=\mathrm{T}$ (accessed 16/05/2018).

GBCSA (Green Building Council South Africa) (2018) Building Green Costs on Average Only 5\% More Than Conventional Building. Study. GBCSA, Cape Town, South Africa. See https://gbcsa.org. za/building-green-costs-on-average-only-5-more-than-conventionalbuilding-study/ (accessed 14/06/2018).

Gold G (2013) Design of Individual and Community-Scale Rainwater Harvesting Systems for Domestic Water Use in Austin. The University of Texas at Austin Texas, Austin, TX, USA.
Habitat 3 (2016) The New Urban Agenda. In Proceedings of the United Nations Conference on Housing and Sustainable Urban Development, Quito, Ecuador. United Nations, New York, NY, USA, pp. 1-66.

Harris J (2016) The End of Council Housing. The Guardian, 4 January. See https://www.theguardian.com/society/2016/jan/04/end-of-councilhousing-bill-secure-tenancies-pay-to-stay (accessed 21/05/2018).

HD (Homes Direct) (2018) Average Cost of a Manufactured Home in 2018. HD, Salida, CA, USA. See https://www.thehomesdirect.com/blog/ average-cost-of-a-manufactured-home (accessed 20/05/2018).

Hong N (2016) Customer Value in Sharing Economy. Master's thesis, University of Tampere, Tampere, Finland.

Jobs S (2007) Macworld Conference and Expo Keynote 2007. Genius, San Francisco, CA, USA. See https://genius.com/Steve-jobsiphone-keynote-2007-annotated (accessed 28/05/2018).

Jones S and Laquidara-Carr D (2016) The Drive Toward Healthier Buildings 2016: Tactical Intelligence to Transform Building Design and Construction. Dodge Data \& Analytics, New York, NY, USA, SmartMarket Report.

Kochera A, Straight A and Guterbock T (2005) Beyond 50.05: A Report to the Nation on Livable Communities: Creating Environments for Successful Aging. American Association of Retired Persons, National Academies Press, Washington, DC, USA.

Kottke T, Abariotes A and Spoonheim JB (2018) Access to affordable housing promotes health and well-being and reduces hospital visits. The Permanente Journal 22: 17-079. https://doi.org/ 10.7812/TPP/17-079.

Kuo FE and Sullivan WC (2001) Environment and crime in the inner city - Does vegetation reduce crime? Environment and Behavior 33(3): 343-367.

Landreneau A (2017) Green Buildings Don't Have to Cost More. Building Design + Construction, Arlington Heights, IL, USA. See https://www.bdcnetwork.com/blog/green-buildings-dont-havecost-more (accessed 14/06/2018).

Love B (2017) Paris Plans to Banish All But Electric Cars By 2030. Thomson Reuters, Paris, France. See https://www.reuters. com/article/us-france-paris-autos/paris-plans-to-banish-all-butelectric-cars-by-2030-idUSKBN1CH0SI (accessed 14/03/2018).

Lutz R (2017) Kiss the Good Times Goodbye, Redesigning the Industry, Part 1 - Visionaries. Automotive News, Detroit, MI, USA. See http://www.autonews.com/article/20171105/INDUSTRY_ REDESIGNED/171109944/industry-redesigned-bob-lutz (accessed $14 / 03 / 2018)$.

Madden S (2010) Choosing Green Over Gray: Philadelphia's Innovative Stormwater Infrastructure Plan. Master's thesis, Massachusetts Institute Technology, Cambridge, MA, USA.

McCahill C and Garrick N (2012) Automobile use and land consumption: empirical evidence from 12 cities. Urban Design International 17(3): 221-227, https://doi.org/10.1057/udi.2012.12.

McMahon E (2000) Looking around: green infrastructure. Planning Commission Journal 37: 4-7.

Melia S and Shergold I (2016) Pedestrianisation and Politics: Evidence Gaps and a Case Study of Brighton's Old Town. Universities Transport Study Group, Bristol, UK.

MFG (Mortgage Finance Gazette) (2018) Shared Ownership: Perceived Risks and Potential Rewards for Lenders. MFG, Croydon, UK. See https://www.mortgagefinancegazette.com/features/sharedownership-perceived-risks-potential-rewards-lenders-14-02-2018/ (accessed 13/06/2018).

Michaels G (2016) Why Are So Many People Still Living in Flood-Prone Cities? The Conversation, Boston, MA, USA See http://theconversation.com/why-are-so-many-people-still-livingin-flood-prone-cities-55281 (accessed 14/06/2018). 
Miller SN, Kepner WG, Mehaffey MH et al. (2002) Integrating landscape assessment and hydrologic modeling for land cover change analysis. Journal of the American Water Resources Association 38(4): 915-929.

Modulartoday (2018) Modular Homes, Mobile Homes \& Traditional Homes Compared. Modulartoday. See https://www.modulartoday. com/comparison.html (accessed 20/05/2018).

Mtantato S (2013) Impact of Current Land-use Patterns on Public Transport and Human Settlements. Financial and Fiscal Commission, Cape Town, South Africa, Submission for the 2012/13 Division of Revenue - Technical Report.

Nosowitz D (2018) 10 Numbers That Show How Much Farmland We're Losing to Development - Modern Farmer. Modern Farmer Media, Hudson, NY, USA. See https://modernfarmer.com/2018/05/10numbers-that-show-how-much-farmland-were-losing-todevelopment/ (accessed 14/06/2018).

Nyren R (2014) Senior's Housing Outlook. Urban Land, 28 July. Urban Land Magazine, Washington, DC, USA. See https:/urbanland.uli. org/news/seniors-housing-outlook (accessed 18/05/2018).

Oswald A, Proto E and Sgroi D (2011) New Study Shows We Work Harder When We are Happy. University of Warwick, Coventry, UK. See https://warwick.ac.uk/newsandevents/pressreleases/new study_shows/ (accessed 13/06/2018).

Parker C (2016) Bringing old and young together benefits both. Stanford News. See https://news.stanford.edu/2016/09/08/older-people-offerresource-children-need-stanford-report-says/ (accessed 14/06/2018).

Philbeck T (2017) Navigating the next industrial revolution. In The Fourth Industrial Revolution: Proceedings of a Workshop - in Brief (Frueh S (ed.)). National Academies Press, Washington, DC, USA, pp. 1-2.

Pike E (2011) Opportunities to Improve Tire Energy Efficiency. International Council on Clean Transportation, Washington, DC, USA.

Sayal J, Densmore AL and Carboneau P (2014) Analyzing the effect of land-use/cover changes at sub-catchment levels on downstream flood peaks: a semi-distributed modeling approach with sparse data. CATENA 118: 28-40.

SCN (State Council News) (2017) China Issues Five-Year Plan on Elderly Care. SCN, Beijing, China. See http://english.gov.cn/policies/latest_ releases/2017/03/06/content_281475586946296.htm/ (accessed $16 / 05 / 2018)$.

Scott G (2018) The Impact of George Peabody, the First Modern Philanthropist. Inverse, New York, NY, USA. See https://www. inverse.com/article/42409-george-peabody-philanthropist-peabodyfund (accessed 13/06/2018).

SD (Science Daily) (2017) Brake Dust May Cause More Problems than Blackened Wheel Covers. SD, Rockville, MD, USA. See https://www.sciencedaily.com/releases/2017/03/170303091332.htm/ (accessed 16/05/2018).

SDC (Sustainable Development Commission) (2014) Fairness in a Car Dependant Society. The Stationary Office, Norwich, UK.

Seeland K, Dubendorfer S and Hansmann R (2009) Making friends in Zurich's urban forests and parks: the role of public green space for social inclusion of youths from different cultures. Forest Policy and Economics 11(1): 10-17.

Seymour M, Wolch J, Reynolds KD and Bradbury H (2010) Resident perceptions of urban alleys and alley greening. Applied Geography 30(3): 380-393.

Shoup D (2014) The high cost of minimum parking requirements. In Parking Issues and Policies (Transport and Sustainability, Volume 5) (Ison S and Mulley C (eds)). Emerald Group Publishing Limited, Bingley, UK, pp. 87-113.

Smith C (2016) Forget Driverless Cars, Someone Made an Autonomous Personal Transportation Drone. The Woodlands, TX, USA. See http://bgr.com/2016/01/07/ehang-184-personal-transportationdrone/ (accessed 18/05/2018).

Sullivan F (2018) Paris Gets Serious About Free Transit. Citylab, Washington, DC, USA. See https://www.citylab.com/ transportation/2018/05/paris-ponders-an-audacious-idea-freetransit-for-all/560522/?utm_source $=$ citylab-daily\&silverid $=$ MzI5ODU0MDkyNzUwS0 (accessed 18/05/2018).

Tong Z (2017) Review of the application of green building and energy saving technology. In IOP Conference Series (Tong Z (ed.)). Earth and Environmental Science, Singapore, Singapore, vol. 100, pp. 3-4.

UNDESA (United Nations, Department of Economic and Social Affairs) (2014) World Urbanization Prospects: The 2014 Revision. Highlights Population Division, Department of Economic and Social Affairs, United Nations Secretariat, New York, NY, USA (ST/ESA/SER.A/352).

Vandermeulen V, Verspecht A, Vermeire B, Van Huylenbroeck $G$ and Gellynck X (2011) The use of economic valuation to create public support for green infrastructure investments in urban areas. Landscape and Urban Planning 103(2): 199-203, https://doi.org/ 10.1016/j.landurbplan.2011.07.010.

WA (Wards Auto) (2017) U.S. Car and Truck Sales, 1931-2016. WA, Detroit, MI, USA. See http://wardsauto.com/datasheet/ us-car-and-truck-sales-1931-2014 (accessed 14/03/2018).

Wachsmuth D, Kerrigan D, Chaney D and Shillolo A (2017) Short-term Cities Airbnb's Impact on Canadian Housing Market. McGill University, Montreal, Quebec, Canada.

Wallström M (2007) Reclaiming City Streets for People: Chaos or Quality of Life. Directorate-General for the Environment, European Commission, Brussels, Belgium.

Wang Y (2017) The Development of Security and Whole Care System for the Aged in China. Springer, Singapore.

Young RK (2015) Seoul's Flood Control Policy. Seoul Solution, Seoul, Korea. See https://seoulsolution.kr/en/node/3525 (accessed $14 / 03 / 2018$ )

Zart N (2017) The Ehang 184 Passenger Drone Wants To Take You Into The Air. Cleantechnica. See https://cleantechnica. com/2017/12/29/ehang-184-passenger-drone-wants-take-air/ (accessed 16/05/2018).

Zhang B, Xie G, Zhang C and Zhang J (2012) The economic benefits of rainwater-runoff reduction by urban green spaces: a case study in Beijing, China. Journal of Environmental Management 100: 65-71, https://doi.org/10.1016/j.jenvman.2012.01.015.

\section{How can you contribute?}

To discuss this paper, please email up to 500 words to the editor at journals@ice.org.uk. Your contribution will be forwarded to the author(s) for a reply and, if considered appropriate by the editorial board, it will be published as discussion in a future issue of the journal.

Proceedings journals rely entirely on contributions from the civil engineering profession (and allied disciplines). Information about how to submit your paper online is available at www.icevirtuallibrary.com/page/authors, where you will also find detailed author guidelines. 